Original Research Paper

\title{
Effect of Cadmium on Worker Ovary Morphology of Bombus morio (Hymenoptera: Bombini)
}

\author{
${ }^{1,2}$ Fábio Camargo Abdalla, ${ }^{2}$ Marina Pedrosa, \\ ${ }^{1}$ Caio Eduardo da Costa Domingues and ${ }^{1,2}$ Paulo José Balsamo

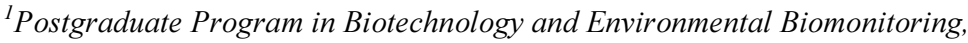 \\ Federal University of São Carlos, UFSCar, Campus Sorocaba, Sorocaba, Brazil \\ ${ }^{2}$ Department of Biology, Laboratory of Structural and Functional Biology (LABEF), \\ Federal University of São Carlos, UFSCar, Campus Sorocaba, Sorocaba, Brazil
}

\author{
Article history \\ Received: 16-12-2017 \\ Revised: 26-03-2018 \\ Accepted: 09-04-2018 \\ Corresponding Author: \\ Fábio Camargo Abdalla \\ Postgraduate Program in \\ Biotechnology and \\ Environmental Biomonitoring, \\ Federal University of São \\ Carlos, UFSCar, Campus \\ Sorocaba, Sorocaba, Brazil \\ Email: fabdalla@ufscar.br
}

\begin{abstract}
Bees are valuable bioindicators, providing information regarding environmental conditions through different kinds of analyses. Therefore, the effect of cadmium on the morphology of ovaries of Bombus morio workers was used to study a concentration considered environmentally safe $(1 \mathrm{ppb})$ in Brazil. Workers of the same estimated age exposed for $48 \mathrm{~h}$ to 1 ppb cadmium showed extensive morphological changes in the germarium and vitellarium compared with the control group. Bees exposed to cadmium showed death of or damage to entire vitellogenic follicles, with chromatin condensation and fragmentation of nurse cell nuclei. In the germarium, the intercellular bridge connecting the primary oocyte to the developing nurse cells was broken. The nurse cells formed a cluster of cells with compacted chromatin, detached from an isolated primary oocyte. In some cases, the cytoblasts were absent from the germarium, leaving an empty space surrounded by collapsed peritoneal sheaths. We further propose that such a hazardous impact of $1 \mathrm{ppb}$ cadmium on the ovaries of $B$. morio workers is not only mainly due to cadmium itself as an endocrine disruptor, indirect oxidative stress promoter, cytoskeleton destabilizer and mutagenic trace metal, but by disruption of the trophocytes, where perivitelline space filled with eosinophil material in the control group, was totally empty in exposed bees, suggesting interruption of trophocyte vitellogenin production.
\end{abstract}

Keywords: Biomarker, Bombus Morio, Ecotoxicology, Morphology, Ovary

\section{Introduction}

In addition to the invaluable pollination services of bees, these insects are also successful bioindicators. Thus, they can provide information regarding environmental risk assessment via several methods of analysis. Hence, bees have been the subject of investigations ranging from the study of their mortality rate and the presence of residual contaminants in their nests to physiological, morphological and molecular studies on their tissues and cells (Celli and Maccagnani, 2003).

Regarding the genus Bombus, a sudden decline and loss of populations of several species have been recorded annually worldwide (Celli and Maccagnani, 2003; Martins and Melo, 2010; Cameron et al., 2011; Gradish et al., 2011; Carswell, 2015; Rhoades et al., 2016). The causes of such dramatic changes in the populations of these species are multifactorial and they act together to pose a serious threat to bees (Martins and Melo, 2010). Some causes of the mass death of bees are well defined, such as global warming, intensive agricultural activity, mining and industrialization (Gradish et al., 2011; Martín et al., 2015; Dicks et al., 2016; Potts et al., 2016).

Anthropogenic interference with the environment has resulted in bees being exposed to high levels of xenobiotics, disturbing and contaminating the natural balance among bees and their biomes and unbalancing the relationships between bees and natural parasites and predators (Celli and Maccagnani, 2003; Pywell et al., 2006; Gallai et al., 2009; Grixti et al., 2009; Martins and Melo, 2010; Cameron et al., 2011; Gradish et al., 2011; Abdalla et al., 2014; Goulson et al., 2015; Martín et al., 2015; Dicks et al., 2016; Potts et al., 2016; Woodcock et al., 2016; Domingues et al., 2017). 
The increased need for the extraction of trace metals and metalloids used in the pharmaceutical, industrial and commercial technological production chains does not only destroy entire biomes, it can also release and disperse numerous types of highly hazardous trace metals into the environment through several types of biological and geological processes (Duruibe et al., 2007; Sims et al., 2013). Notably, the fraction of solid waste consisting of metals and metalloids, such as mercury, has increased markedly in the past few decades (Bernardes et al., 2004; Martín et al., 2015).

Numerous trace metals, such as mercury, copper, selenium, lead and cadmium, have been found in the nectar, resin, pollen and nests of Apis spp. and stingless bees (Roman, 2010; Carrero et al., 2013; Johnson, 2015). Trace metals are very harmful and their concentrations in the environment have been increasing, making them an important risk factor for bees (Celli and Maccagnani, 2003; Duruibe et al., 2007; Roman, 2010; Carrero et al., 2013). These metals are highly cationic elements in organic systems, given that they are converted into a stable oxidation state in acidic $\mathrm{pH}$, a condition that exists in the stomach of all animals. The highly reactive cationic trace metals bind to DNA, proteins and enzymes, disturbing the whole metabolic system of the organism. The trace metals usually bond to sulfhydryl groups (-SH) of cysteine and sulfur atoms of methionine $\left(-\mathrm{SCH}_{3}\right)$, inhibiting and/or interfering with the enzymatic and DNA functions, causing a general metabolic disturbance, endocrine disruption, mutagenesis, cytotoxicity and genotoxicity (Duruibe et al., 2007; Ruttkay-Nedecky et al., 2013).

Cadmium $(\mathrm{Cd})$, a by-product of zinc mining exploration, is one of the most dangerous trace metals and causes all sorts of damage, as mentioned above (Godt et al., 2006; Abdalla and Domingues, 2015; Wallace, 2015). Moreover, $\mathrm{Cd}$ can also be found as a component of agrochemicals, enhancing the harmful effects of such toxicants on the non-target entomofauna, especially bees (WHO, 2011; Wallace, 2015).

Studies associate $\mathrm{Cd}$ with a wide spectrum of deleterious effects on the reproductive tissues, including ovaries (Soares et al., 2013). The oviposition rate, hatchability and fecundity of female adults are impaired by exposure to cadmium. Cadmium exposure also delays ovarian maturation, inhibits vitellogenesis and changes the ultrastructure of cells in ovary tissues (Cervera et al., 2005; 2006; Abdalla and Domingues, 2015; PłachetkaBożek et al., 2018). In addition, Cd can induce apoptosis in chicken ovarian tissue and decrease activities of SOD and GPx (Yang et al., 2012; Wan et al., 2017). When Cd exposure occurs in rats from weaning to maturity, $\mathrm{Cd}$ decreases ovarian wet weight and ovarian/body weight ratios and increases follicle apoptosis (Weng et al., 2014). Cadmium can also decrease male fertilization rate and sperm mobility (Zhao et al., 2017). In tadpoles of Lithobates catesbeianus (Shaw, 1802), Cd exposure provoked important anatomical changes on gonads, from total reabsorption to polygonadism and sex reversal (Abdalla et al., 2013).

The internal organs of bees are sensitive biomarkers for monitoring the effects of environmental stress, especially of those stresses that are directly related to reproduction and general metabolic homeostasis (Abdalla and Domingues, 2015). It is imperative to study the internal organs of bees to understand how and why bees die when exposed to xenobiotics and trace metals, however, the internal organs are frequently overlooked in ecotoxicological studies of bees (Landa et al., 1983; Forkpah et al., 2014; Skaldina and Sorvari, 2017).

According to the World Health Organization (WHO, 2011), the cadmium limit for drinking water is $3 \mathrm{ppb}$. In Brazil, the trace metal concentration in the water is regulated by the Brazilian Environmental Council (CONAMA) (2005), which considers a concentration of $1 \mathrm{ppb}$ cadmium to be environmentally safe for class 1 and class 2 water. Such water is used in the domestic supply after simplified (class 1) or conventional (class 2) treatment, it is also used for recreation, the irrigation of vegetables and fruits and the protection of aquatic communities (CONAMA, 2005). Both in the countryside and in urban areas, bees have access to these types of water. Therefore, the presence of trace metals in the water an important route for poisoning, possibly contributing to the disappearance of bees (WHO, 2011; Johnson, 2015).

We investigated the effect of $1 \mathrm{ppb}$ cadmium on the ovaries of Bombus morio to verify if the cadmium concentration considered environmentally safe impacts the cells of the reproductive biology of the females. As the colony biological cycle of $B$. morio begins with one fecundated solitary queen, or solitary phase, these bees are predisposed to be more susceptible to environmental impacts.

\section{Materials and Methods}

\section{Bee Collection}

Workers of Bombus morio (Swederus, 1787) were collected from the remaining fragments of the semideciduous forest and Cerrado in the municipality of Sorocaba $\left(23^{\circ} 34 \square \quad 53.10 \quad\right.$ S $47^{\circ} 31 \square \quad 29.5 \square \quad$ W), state of São Paulo, Brazil. All workers were collected from Cassia sp. Linnaeus (1753) flowers between 9 am and 11:30 am. Bees were collected individually with an entomological net and immediately transferred to a 50 $\mathrm{mL}$ Falcon tube (one bee per tube). All Falcon tubes containing bees were kept in a thermic box in the dark to avoid stressing the bees. 


\section{Ecotoxicological Bioassay}

The workers were kept individually in plastic boxes that were $10 \times 14 \times 10 \mathrm{~cm}$ with two feeders glued to the bottom of the box (close to the wall), including one for food and another for water or the contaminated solution and the boxes were kept inside an incubator $\left(31^{\circ} \mathrm{C}, \mathrm{RH}\right.$ $70 \%$, in the dark). The bees were fed ad libitum with a solid mixture of honey, dehydrated pollen and organic soy flour. Bioassays were conducted with replicates for both the control and experimental groups $(n=11$ for each). The control group was offered $2 \mathrm{~mL}$ of water and the experimental group was offered $2 \mathrm{~mL}$ of cadmium solution (cadmium chloride; Sigma-Aldrich, $\geq 99.5 \%$

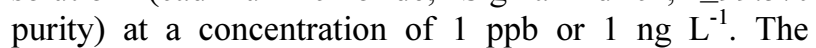
dilution calculations were made only with the cadmium molecular weight. After $48 \mathrm{~h}$ of exposure, all bees were sacrificed by cryo-anesthesia (bees were hibernated at $4^{\circ} \mathrm{C}$ for 30 minutes before being dissected) and the ovaries of the bees were dissected directly in a fixative solution.

No formal permission or ethical form submission was required for the areas where the bees were collected.

\section{Preparation of the Material for Light Microscopy}

The ovaries were dissected and fixed in $4 \%$ paraformaldehyde in $0.2 \mathrm{M}$ sodium phosphate buffer ( $\mathrm{pH}$ 7.4), following preparation by slow dehydration in increasing ethanol solutions according to the methodology described by Silva-Zacarin et al. (2012). Upon fixation, the material was embedded in JB-4 resin (Leica Biosystems Nussloch GmbH, Heidelberg, Germany), according to the manufacturer's recommendations. Histological sections of $1.5 \mu \mathrm{m}$ thickness were cut with a Leica microtome (RM 2255) and stained with hematoxylin and eosin (Merck). The material was analyzed using a Leica light microscope (DM 1000).

\section{Results and Discussion}

\section{Morphology of the Worker Ovary of the Control Group}

The ovarian cycle and general morphology of the ovarioles of non-exposed bees were typical of polytrophic meroistic ovaries, as described for other bee species (Martins and Serrão, 2004; Tanaka and Hartfelder, 2004; Tanaka et al., 2009; Chapman, 2012), i.e., each ovariole was comprised of a terminal filament, germarium and vitellarium (Fig. 1A, Fig. 1E). The terminal filament was short and continuous with the anterior end of the germarium (Fig. 1A). The germarium: was in the proximal region of the ovarioles; was below and continuous with the terminal filament (Fig. 1A); contained the germ cells, mainly cytoblasts and clusters of cystocytes at different stages of development (Fig. 1B-C); and was permeated by small somatic cells or prefollicular cells (Fig. 1C). Also in the germarium, the nurse cells, oocyte and primordial pre-vitellogenic follicles had begun to differentiate (Fig. 1B-C). The initial development of the follicles was marked by a larger cell, the primary oocyte, with an aggregation of smaller cells, the early nurse cells, closely associated with the primary oocyte (Fig. 1C). In contrast, the vitellarium occupied the distal region of the ovariole and contained vitellogenic ovarian follicles at various stages of development (Fig. 1D-E).

Mature ovary follicles were divided into two distinguishable chambers that wereare covered by mature follicular cells (Fig. 1E). Two distinct chambers, the nurse chamber and the oocyte chamber, formed an ovarian follicle (Fig. 1E). They wereare arranged such that the follicles of the proximal region differed from the distal follicles. The most developed follicles were in the distal portion of the ovariole and the newly developed follicles, with small, early vitellogenic oocytes and large nurse chambers, were in the proximal portion of the ovariole, near the least differentiated portion of the germarium. Each chamber contained an oocyte and many nurse cells (Fig. 1E) that were connected through communication via intercellular bridges (Snodgrass, 1956; Chapman, 2012).

The main function of the nurse cells is to provide the oocyte with macromolecules, such as mRNA, rDNA, lipids and organelles (e.g., mitochondria); the yolk is provided indirectly by the follicular cells (Telfer et al., 1982). The yolk is produced by trophocytes as a protein precursor, which is released into the hemolymph and subsequently taken up by follicular cells. During vitellogenesis, the vitellogenin is exocytosed into the space between the follicular epithelium (Fig. 1E) and the vitellogenin and from that space, is endocytosed by the oocyte (Telfer et al., 1982; Fleig, 1995; Zelazowska, 2005).

The entire ovariole was surrounded outside by a cellular peritoneal sheath and by an inner non-cellular tunica propria (Fig. 1A-E). Although not shown in the present work, follicular abortion and the corpus luteum were also observed, which is a normal condition in the ovarian development of this and other species of bees; this morphology is found mainly in queens but can also be observed in egg-laying workers (Berger and Abdalla, 2005; Berger et al., 2005; Patrício and Cruz-Landim, 2008; Tanaka et al., 2009).

\section{Morphology of the Worker Ovary when Exposed to Cadmium}

In the germaria of cadmium-exposed bees, the follicular epithelium was unstructured, with the follicular cells detached from each other, or absent, or even organized in clusters of cells with very fragmented condensed chromatin remaining inside the lumen by the tunica propria and peritoneal sheath 
(Fig. 2A-C, Fig. 3B-C). In a more advanced stage of early oogenesis, the intercellular connection between the oocyte and the nurse cells was broken (Fig. 2B) and the nurse cells became isolated (Fig. 2B-C). In addition, in this case, the follicular layer was incomplete and the isolated oocyte presented signs of nucleus disruption, with loss of the shape of the nucleus, which ranged in shape from spherical to very sinuous (Fig. 2B-C). The previtellogenic follicles showed disorganization of the nurse cells or of entire pre-follicles (Fig. 2B-D). Both in the germarium and in the vitellarium, the peritoneal sheath was quite thick (Fig. 2A, Fig. 2D).

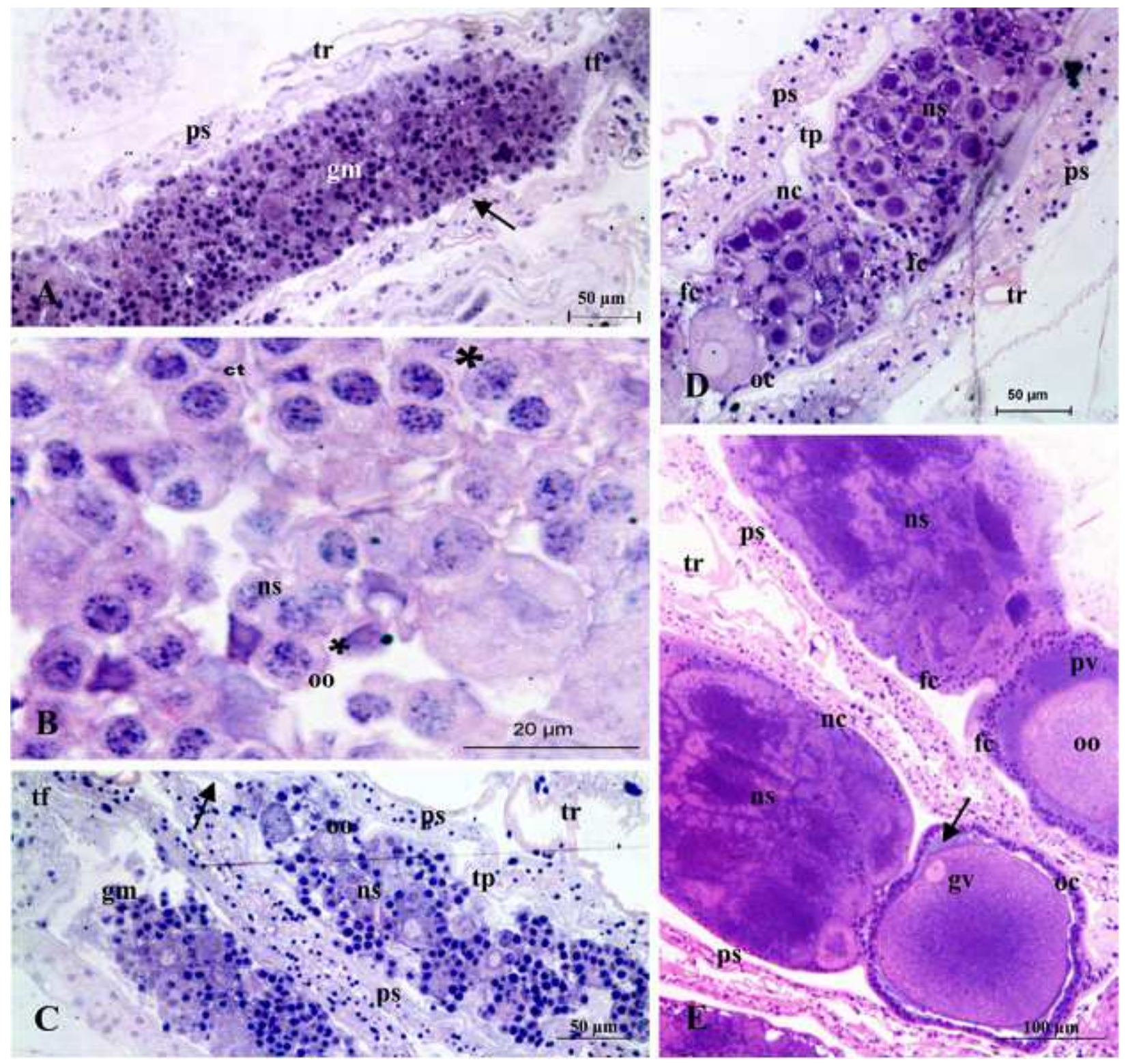

Fig. 1: Morphology of the ovaries of B. morio workers not exposed to cadmium. (A) A germarium (gm) enclosed by an outer peritoneal sheath (ps) and tracheoles (tr) and an inner non-cellular tunica propria (arrow). The germarium is continuous with the terminal filament (tf). (B) Detail of the germarium with cystocytes (ct) undergoing differentiation (asterisk). Some groups of cystocytes present a developing oocyte (oo) connected to the smaller nurse cells (ns). (C) Detail of the germarium (gm) with cysts differentiated into an oocyte (oo) that is linked to smaller, differentiated nurse cells (ns). (D) Vitellarium with differentiating pre-vitellogenic follicles, showing developing nurse (nc) and oocyte (oc) chambers and follicular cells (fc). (E) Vitellogenic follicles with defined nurse chambers: surrounded by somatic cells (sc), where nurse cells (nc) and an oocyte (oo) developed; and surrounded by the follicular cells (fc), which form the nurse (nc) and oocyte (oc) chamber. Notice the oocyte (oo) with yolk and germinal vesicle (gv). The perivitelline space (pv) contains basophilic material inside (arrow) 

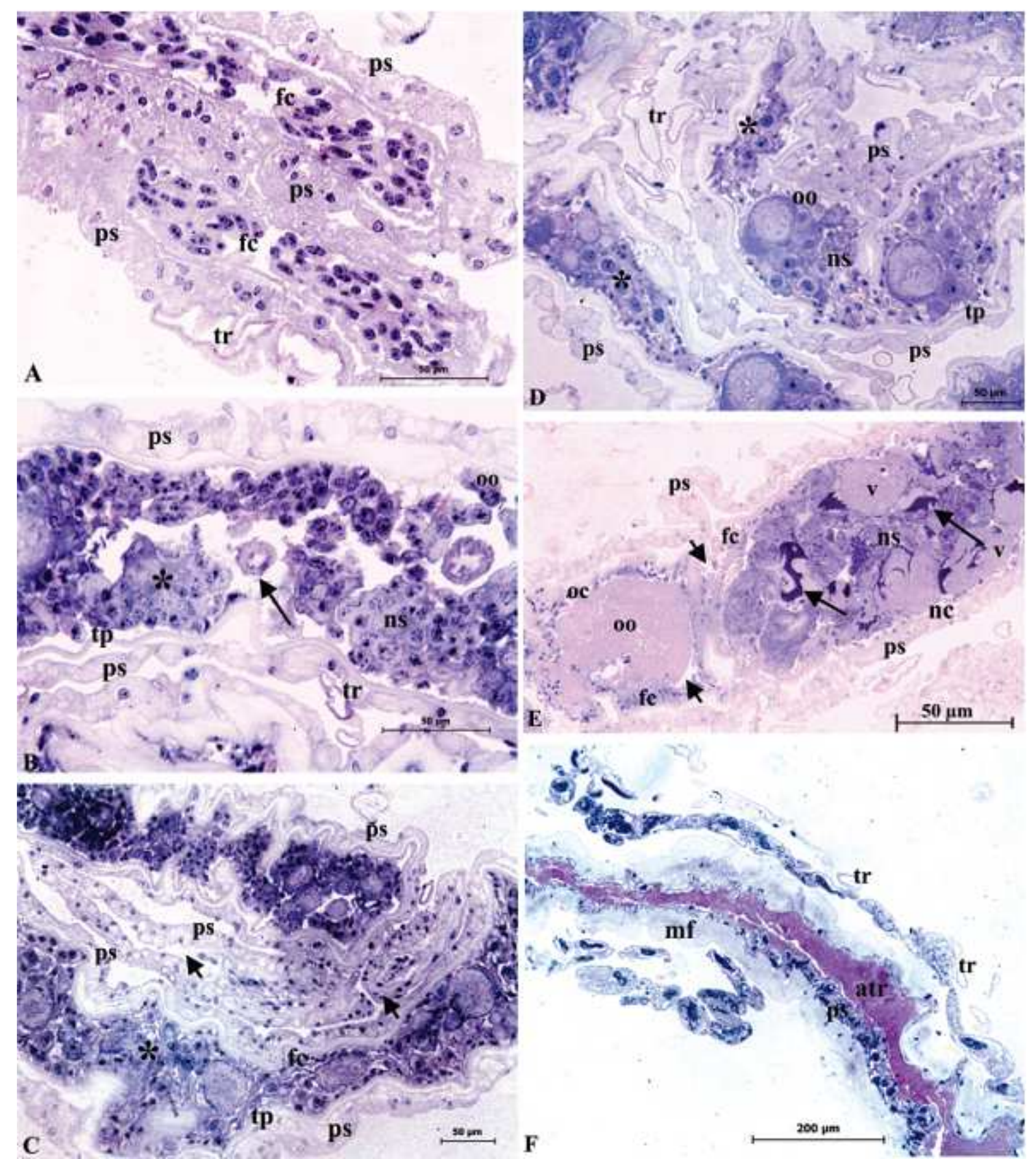

Fig. 2: Morphology of the ovaries of B. morio workers that have been exposed to cadmium. (A) Ovarioles of a germarium enclosed by a thick peritoneal sheath (ps) filled with follicular cells (fc) and tracheoles (tr). (B) Ovarioles of a germarium with disorganized pre-follicles (asterisk), detached (arrow) oocytes (oo) and a mass of dying nurse cells (ns). Note the thick peritoneal sheath (ps) and tunica propria (tp). (C) The germarium with the ovarioles described in panels (A) and (B) showing collapsed peritoneal membranes with empty lumens (arrowheads). (D) A subset of pre-vitellogenic ovarioles show degeneration of the nurse cells (asterisk). (E) A vitellogenic follicle showing nurse cells (ns) with large vacuoles (v) and compacted, fragmented chromatin (arrow). Note the oocyte (oo) with signs of degeneration. Notice in the nurse (nc) and oocyte chambers (oc), disrupted follicular cells (fc) and emptiness of the perivitelline space (arrowheads) (F) The posterior portion of the vitellarium showing atresia (atr) of an entire follicle. Follicle atresia is characterized by destruction of the follicular cells and both nurse and oocyte chamber, forming a mass of basophilic nature covered by a thick and disrupted peritoneal sheath (ps) and muscle fiber (mf) 


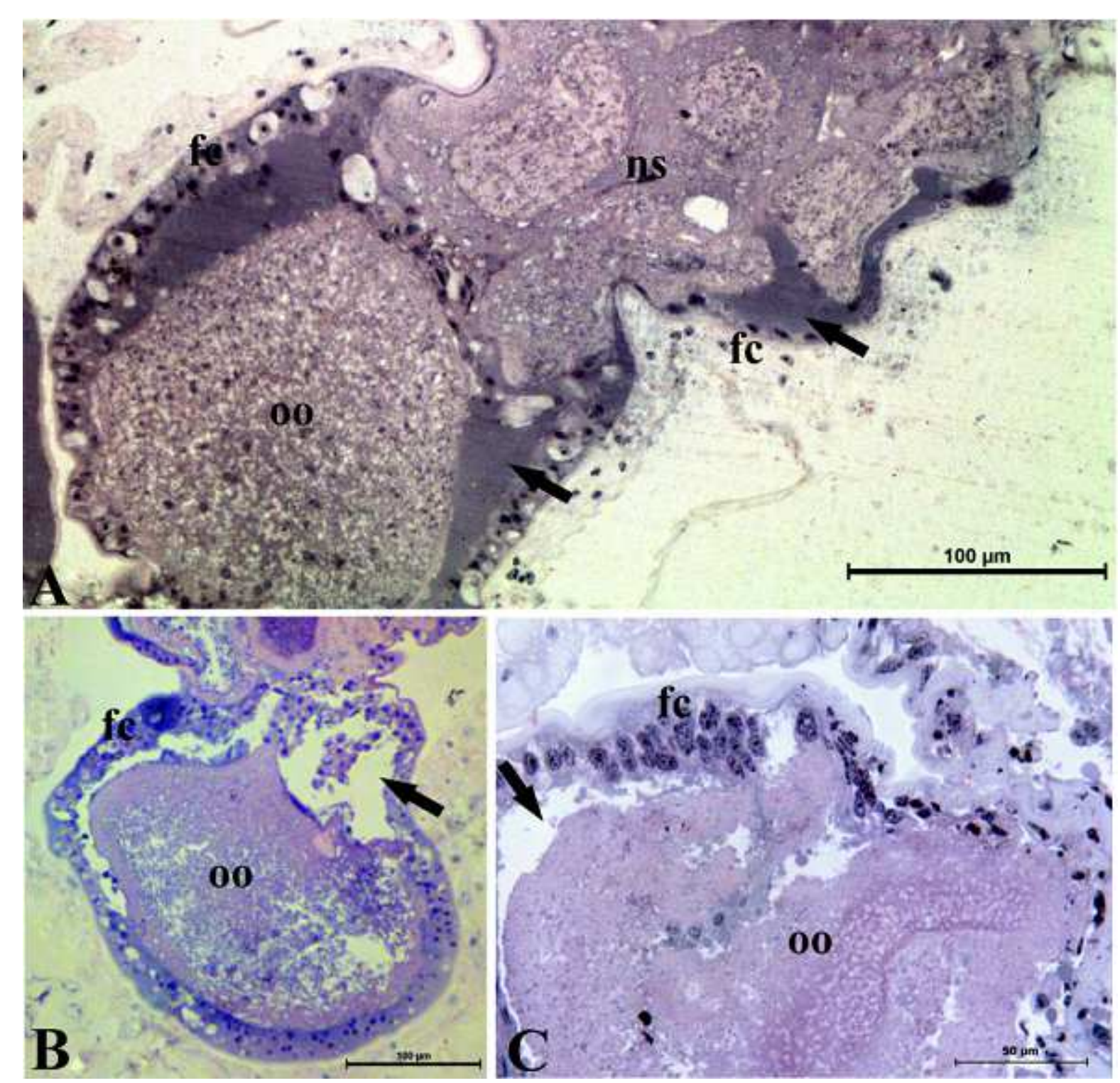

Fig. 3: Detail of the follicular cells and perivitelline space in ovaries of B. morio workers control and exposed to 1 ppb cadmium. (A) Follicle of a non-exposed worker, showing the follicular cells (fc) surrounded by a well-developed perivitelline space with basophilic material inside (arrow). Notice the nurse cells with decondensed chromatin (ns) and a typical initial oocyte (oo). (B) Detail of the oocyte chamber of an exposed worker, showing a vacuolated, unshaped oocyte (oo) and the emptiness of the perivitelline space (arrow). (C) Detail of the follicular epithelium disruption of the oocyte chamber. Notice the disruption of the epithelium of follicular cells ( $\mathrm{fc}$ ) and the emptiness of the perivitelline space (arrow)

All these ovarian alterations occurred in the previtellogenic phase or with the initial development of the ovarian follicles. This ovarian phase does not depend on any exogenous stimuli and other than the fact that the fat body may supply the primary oocyte with some compounds for initial development, its participation in ovarian development begins in the vitellogenic phase, which depends on exogenous stimuli, such as mating (Tanaka and Hartfelder, 2004; Berger et al., 2005).

The death of nurse cells culminates in the full development of an oocyte (Reginato and Cruz-Landim,
2003; Tanaka et al., 2009), but what was observed in the ovaries of cadmium-exposed bees is the death of or damage to entire follicles (Fig. 2F), with chromatin condensation of the nurse cells in the initial (Fig. 2B-C) and advanced vitellogenic follicles (Fig. 2D). In addition, extreme fragmentation and compaction of the nurse cell chromatin were observed in vitellogenic follicles, which contained severe vacuolization of the cytoplasm (Fig. 2E, Fig. 3C). The most remarkable result concerning the perivitelline space was that it was filled with eosinophil material in the control group (Fig. 3A), 
whereas in exposed bees, it was totally empty (Fig. 3B). The follicular epithelium had clearly broken down (Fig. 3B-C) and the oocyte appeared vacuolated and misshapen (Fig. 3B), providing strong evidence that the vitellogenin transfer from the follicular cells (Telfer et al., 1982) was blocked stopped in cadmiumexposed bees. In an extreme case, the oocyte and nurse chambers were totally degenerated, forming an acidophilic homogenous mass with a very thick and atypical peritoneal sheath (Fig. 2F). The peritoneal sheath cells showed signs of cell death, with cytoplasm vacuolization and very condensed chromatin (Fig. 2F), a condition called follicle atresia (Uchida et al., 2004).

From a broader perspective, the pronounced effect of cadmium exposure on the ovaries of workers of $B$. morio can affect several aspects of the biology of this species. Cadmium may have a synergetic effect on the ovaries of $B$. morio workers: it may act directly on the entire ovary but may also affect the cells of the HNS (Abdalla and Domingues, 2015), primarily by affecting trophocytes, which supply all the vitellogenin to the follicular cells, which then release the vitellogenin for the oocyte (Telfer et al., 1982; Fleig, 1995; Zelazowska, 2005). Cadmium also severely compromised the availability of nutrients in the hemolymph because, as previously described by Abdalla and Domingues (2015), all the pericardial cells exposed to $1 \mathrm{ppb}$ cadmium in $B$. morio workers were at stage IV, i.e., maximum capacity for hemolymph absorption. This leads to a decrease in the availability of not only vitellogenin but also other nutrients in the hemolymph; hemolymph is intensively sequestered by the pericardial cells, dramatically reducing the cycling of hemolymph into the hemocoel. The emptiness of the perivitelline space and the disruption of the follicular cells in cadmiumexposed bees are in accordance with the total disruption of trophocytes of $B$. morio exposed to cadmium (Abdalla and Domingues, 2015).

At the molecular and biochemical levels, cadmium exerts its toxic effects by replacing the co-factor of the metalloenzymes and metalloestrogens, such as the metallothioneins, a group of enzymes involved in protecting the natural and essential metal ion homeostasis and also in controlling oxidative stress (Margoshes and Vallee, 1957; Ruttkay-Nedecky et al., 2013; Wallace, 2015). The enzyme co-factor can be substituted for a metal ion of similar size (e.g., zinc for cadmium) and this replacement prevents the enzymes from performing their functions. In most cases, the enzymes are destroyed, disturbing all metabolic homeostasis of the organism (Margoshes and Vallee, 1957; Duruibe et al., 2007). Cadmium can also associate with non-metalloenzymes, interacting with the sulfhydryl radicals of cysteine-rich proteins (Margoshes and Vallee, 1957; Duruibe et al., 2007), such as vitellogenin (Piulachs et al., 2003). Thus, cadmium itself is a potent endocrine disruptor, cytoskeleton destabilizer and mutagenic agent (Godt et al., 2006; Wallace, 2015).

The ovary collapsed in the workers exposed to $1 \mathrm{ppb}$ cadmium and this could also have further implications on the whole biological cycle of the colony of B. morio. As in Bombus terrestris (Garófalo, 1978a; 1978b; Duchateau and Velthuis, 1988), the colony biological cycle of $B$. morio begins with one fecundated solitary queen and at the end of the colony cycle the workers contribute by laying eggs that will develop into males. In this way, the collapse of the cadmium-exposed ovary could affect the foundation of new colonies and the cadmium exposure could also severely impair the fitness and success of new colonies by damaging the ovaries of the workers. Although there is clear evidence of the morphological impacts in bees exposed to cadmium, further studies are required to corroborate some of the aforementioned postulations.

\section{Conclusion}

Although $1 \mathrm{ppb}$ cadmium is considered environmentally safe by the Brazilian Environmental Council (CONAMA) and by the World Health Organization (WHO), this trace metal acted negatively on the ovary morphology of B. morio, leading to the collapse of the ovary in the workers. As a consequence, this is likely to have implications on their reproductive capability and this negative impact may also be extended to include the queens, as well as egg-laying workers.

\section{Acknowledgement}

We thank the Department of Biology (DBio) and Laboratory of Structural and Functional Biology (LABEF) for the use of their facilities.

\section{Funding Information}

Special thanks to the São Paulo Research Foundation, FAPESP (grants 2017/0605-09, 2016/15743-7, 2014/04697-9), for the fellowship in productivity of research (level 2), the Brazilian National Council for Scientific and Technological Development, CNPq (grant 302812/2016-4) and the Coordination Improvement of Higher Education Personnel, CAPES.

\section{Author's Contributions}

Fábio Camargo Abdalla: Supervision and analyses. Marina Pedrosa: Material processing and analyses.

Caio Eduardo da Costa Domingues: Analyses, diagramming and review.

Paulo José Balsamo: Analyses and review. 


\section{Ethics}

The authors have declared that there are no conflicts of interest.

\section{References}

Abdalla, F.C. and C.E.C. Domingues, 2015. Hepatonephrocitic system: A novel model of biomarkers for analysis of the ecology of stress in environmental biomonitoring. PLoS One, 10: 1-9. DOI: 10.1371/journal.pone.0132349

Abdalla, F.C., G. Sampaio, M. Pedrosa, T.P. Sipriano and C.E.C. Domingues et al., 2014. Larval development of Physocephala (Diptera, Conopidae) in the bumblebee Bombus morio (Hymenoptera, Apidae). Rev. Bras. Entomol., 58: 343-348. DOI: $10.1590 / \mathrm{S} 0085-56262014000400003$

Abdalla, F.C., Martins, L.P.A., Silva-Zacarin, E.C.M., Rizzi, G.M. and Costa, M.J. et al., 2013. The impact of cadmium chloride on the gonadal morphology of the north american bullfrog tadpoles, Lithobates catesbeianus (Shaw, 1802). Fresenius Envir. Bull., 22:1962-1966.

Berger, B. and F.C. Abdalla, 2005. Programmed cell death during ovarian differentiation in queens of Apis mellifera Linné, 1758 (Hymenoptera, Apini). Braz. J. Morphol. Sci., 22: 1-4.

Berger, B., F.C. Abdalla and C. Cruz-Landim, 2005. Effect of narcosis with $\mathrm{CO}_{2}$ on the ovarian development in queens of Apis mellifera (Hymenoptera: Apini). Sociobiology, 45: 261-270.

Bernardes, A.M., D.C.R. Espinosa and J.A.S. Tenório, 2004. Recycling of batteries: A review of current processes and technologies. J. Power Sources, 130: 291-298. DOI: 10.1016/j.jpowsour.2003.12.026

Cameron, S.A., J.D. Lozier, J.P. Strange, J.B. Koch and N. Cordes et al., 2011. Patterns of widespread decline in North American bumble bees. PNAS, 108: 662-667. DOI: 10.1073/pnas. 1014743108

Carrero, P., C. Rondón, A.R. Saavedra and P. Vit-Olivier, 2013. A Study of $\mathrm{Hg}$ and $\mathrm{Pb}$ Content in Pot-Honey (Apidae: Meliponini). In: Stingless Bees Process Honey and Pollen in Cerumen Pots, Vit, P. and D.W. Roubik (Eds.), Facultad de Farmacia y Bioanálisis, Universidad de Los Andes, Mérida, ISBN-10: 9789801115519, pp: 1-5.

Carswell, C., 2015. Bumble bees being crushed by climate change. Science. DOI: 10.1126/science.aac8824

Celli, G. and B. Maccagnani, 2003. Honey bees as bioindicators of environmental pollution. B. Insectol., 56: 137-139.

Cervera, A., A.C. Maymó, R. Martínez-Pardo and M.D. Garcerá, 2006. Vitellogenin polypeptide levels in one susceptible and one cadmium-resistant strain of Oncopeltus fasciatus (Heteroptera: Lygaeidae) and its role in cadmium resistance. J. Insect Physiol., 52: 158-68. PMID: 16289568
Cervera, A., A.C. Maymó, R. Martínez-Pardo and M.D. Garcerá, 2005 Vitellogenesis inhibition in Oncopeltus fasciatus females (Heteroptera: Lygaeidae) exposed to cadmium. J. Insect Physiol. 51: 895-911. PMID: 15949812

Chapman, R.F., 2012. The Insects: Structure and Function. 4th Ed., Cambridge University Press, United States of America, ISBN-10: 9780521113892, pp: 959.

CONAMA, 2005. Resolução no 357 de 17 de março de 2005. Dispõe sobre a classificação dos corpos de água e diretrizes ambientais para o seu enquadramento. Conselho Nacional do Meio Ambiente (Brasil).

Dicks, L.V., B. Viana, R. Bommarco, B. Brosi and M.D.C. Arizmendi et al., 2016. Ten policies for pollinators. Science, 354: 975-976.

DOI: $10.1126 /$ science.aai9226

Domingues, C.E.C., F.C. Abdalla, P.J. Balsamo, B.V.R. Pereira and M.A. Hausen et al., 2017. Thiamethoxam and picoxystrobin reduce the survival and overload the hepato-nephrocitic system of the Africanized honeybee. Chemosphere, 186: 994-1005.

DOI: 10.1016/j.chemosphere.2017.07.133

Duchateau, M.J. and H.H.W. Velthuis, 1988. Development and reproductive strategies in Bombus terrestris colonies. Behaviour, 107: 186-207.

Duruibe, J.O., M.O.C. Ogwuegbu and J.N. Egwurugwu, 2007. Heavy metal pollution and human biotoxic effects. Int. J. Phys. Sci., 2: 112-118.

Fleig, R., 1995. Role of the follicle cells for yolk uptake in ovarian follicles of the honey bee Apis mellifera L. (Hymenoptera: Apidae). Int. J. Insect Morphol. Embryol., 24: 427-433. DOI: 10.1016/0020-7322(95)98841-Z

Forkpah, C., L.R. Dixon, S.E. Fahrbach and O. Rueppell, 2014. Xenobiotic effects on intestinal stem cell proliferation in adult honey bee (Apis mellifera $\mathrm{L}$ ) workers. PLoS One, 9: 1-9. DOI: 10.1371/journal.pone.0091180

Gallai, N., J.M. Salles, J. Settele and B.E. Vaissière, 2009. Economic valuation of the vulnerability of world agriculture confronted with pollinator decline. Ecol. Econ., 68: 810-821.

DOI: $10.1016 /$ j.ecolecon.2008.06.014

Garófalo, C.A., 1978a. On the bionomic of Bombus (Fervidobombus) morio (Swederus). I. cell construction and oviposition behavior of the queen (Hymenoptera, Apidae). Revista Brasileira Biol., 38: 227-236.

Garófalo, C.A., 1978b. Bionomics of Bombus (Fervidobombus) morio. II. body size and length of life of worker. J. Apicult. Res., 17: 130-136. DOI: $10.1080 / 00218839.1978 .11099918$ 
Godt, J., F. Scheidig, C. Grosse-Siestrup, V. Esche, P. Brandenburg and A. Reich et al., 2006. The toxicity of cadmium and resulting hazards for human health. J. Occup. Med. Toxicol., 1: 1-6. DOI: $10.1186 / 1745-6673-1-22$

Goulson, D., E. Nicholls, C. Botías and E.L. Rotheray, 2015. Bee declines driven by combined stress from parasites, pesticides and lack of flowers. Science, 347: 1435-1444. DOI: 10.1126/science. 1255957

Gradish, A.E., C.D. Scott-Dupree and G.C. Cutler, 2011. Susceptibility of Megachile rotundata to insecticides used in wild blueberry production in Atlantic Canada. J. Pest Sci., 85: 133-140.

DOI: $10.1007 / \mathrm{s} 10340-011-0391-0$

Grixti, J.C., L.T. Wong, S.A. Cameron and C. Favret, 2009. Decline of bumble bees (Bombus) in the North American Midwest. Biol. Conserv., 142: 75-84. DOI: 10.1016/j.biocon.2008.09.027

Johnson, R.M., 2015. Honey bee toxicology. Ann. Rev. Entomol., 60: 415-434.

DOI: 10.1146/annurev-ento-011613-162005

Landa, V., B. Bennettová, I. Gelbic, S. Matolín and T. Soldán, 1983. Methods for the Assessment of the Effects of Chemicals on the Reproductive Function of Insects. In: Methods for Assessing the Effects of Chemicals on Reproductive Functions, Vouk, V.B. and P.J. Sheehan (Eds.), John Wiley, Chichester, UK, ISBN-10: 9780471105381, pp: 415-438.

Margoshes, M. and B.L. Vallee, 1957. A cadmium protein from equine kidney cortex. J. Am. Chem. Society, 79: 4813-4814. DOI: 10.1021/ja01574a064

Martín, J.A.R., C.D. Arana, J.J. Ramos-Miras, C. Gil and R. Boluda. 2015. Impact of 70 years urban growth associated with heavy metal. Environ. Pollut., 196: 156-163. DOI: 10.1016/j.envpol.2014.10.014

Martins, A.C. and G.A.R. Melo, 2010. Has the bumblebee Bombus bellicosus gone extinct in the northern portion of its distribution range in Brazil? J. Insect Conserv., 14: 207-210. DOI: $10.1007 /$ s 10841-009-9237-y

Martins, G.F. and J.E. Serrão, 2004. A comparative study of the ovaries in some Brazilian bees (Hymenoptera; Apidea). Pap. Avulsos Zool., 44: 45-53. DOI: 10.1590/S0031-10492004000300001

Patrício, K. and C. Cruz-Landim, 2008. Morphological aspects of cell reabsorption in laying queens and workers of Apis mellifera (Hymenoptera: Apidae). Iheringia Sér. Zool., 98: 421-424. DOI: $10.1590 / \mathrm{S} 0073-47212008000400001$

Piulachs, M.D., K.R. Guidugli, A.R. Barchuk, J. Cruz and Z.L.P. Simões et al., 2003. The vitellogenin of the honey bee, Apis mellifera: Structural analysis of the cDNA and expression studies. Insect Biochem. Molec., 33: 459-465.

DOI: $10.1016 / \mathrm{S} 0965-1748(03) 00021-3$
Płachetka-Bożek, A., K. Chwiałkowska and M. Augustyniak, 2018. Molecular changes in vitellogenin gene of Spodoptera exigua after longtime exposure to cadmium - Toxic side effect or microevolution? Ecotoxicol. Environ. Saf. 147: 461-470. DOI: 10.1016/j.ecoenv.2017.08.067

Potts, S.G., V.L. Imperatriz-Fonseca, H.T. Ngo, J.C. Biesmeijer and T.D. Breeze et al., 2016. Summary for policymakers of the assessment report of the Intergovernmental Science-Policy Platform on Biodiversity and Ecosystem Services on pollinators, pollination and food production. Secreta0riat of the Intergovernmental SciencePolicy Platform on Biodiversity and Ecosystem Services. Bonn, Germany.

Pywell, R.F., E.A. Warman, L. Hulmes, S. Hulmes and P. Nuttall et al., 2006. Effectiveness of new agrienvironment schemes in providing foraging resources for bumblebees in intensively farmed landscapes. Biol. Conserv., 129: 192-206. DOI: $10.1016 /$ j.biocon.2005.10.034

Reginato, R.D. and C. Cruz-Landim, 2003. Ovarian growth during larval development of queen and worker of Apis mellifera (Hymenoptera: Apidae): A morphometric and histological study. Braz. J. Biol., 63: 121-127.

DOI: $10.1590 / \mathrm{S} 1519-69842003000100016$

Rhoades, P.R., J.B. Koch, L.P. Waits, J.P. Strange and S.D. Eigenbrode, 2016. Evidence for Bombus occidentalis (Hymenoptera: Apidae) populations in the olympic peninsula, the palouse prairie and forests of Northern Idaho. J. Insect Sci., 16: 1-5. DOI: $10.1093 /$ jisesa/iev155

Roman, A., 2010. Levels of copper, selenium, lead and cadmium in forager bees. Polish J. Environ. Stud., 19: 663-669.

Ruttkay-Nedecky, B., L. Nejdl, J. Gumulec, O. Zitka and M. Masarik et al., 2013. The role of metallothionein in oxidative stress. Int. J. Mol. Sci., 14: 6044-6066. DOI: $10.3390 /$ ijms 14036044

Silva-Zacarin, E.C.M., M.P. Chauzat, S. Zeggane, P. Drajnudel and F. Schurr et al., 2012. Protocol for Optimization of Histological, Histochemical and Immunohistochemical Analyses of Larval Tissues: Application in Histopathology of Honey Bee. In: Current Microscopy Contributions to Advances in Science and Technology, Méndez-Vilas, A. (Ed.), Formatex Research Center, Badajoz, ISBN-10: 9788493984359, pp: 696-703.

Sims, D.B., P.S. Hooda and G.K. Gillmore, 2013. Mining activities and associated environmental impacts in arid climates: A literature review. Environ. Pollut., 2: 22-43. DOI: $10.5539 /$ ep.v2n4p22

Skaldina, O. and J. Sorvari, 2017. Biomarkers of Ecotoxicological Effects in Social Insects. In: Perspectives in Environmental Toxicology, Kesari, K. (Ed.), Springer, Cham, ISBN-10: 9783319462479, pp: 203-214. 
Snodgrass, R.E., 1956. Anatomy of the Honey Bee. 1st Edn., Comstock Publishing Associates, Ithaca, ISBN-10: 9780801404009, pp: 334.

Soares, M.B., A.P. Izaguirry, L.M. Vargas, A.S. Mendez and C.C. Spiazzi et al., 2013. Catechins are not major components responsible for the beneficial effect of Camellia sinensis on the ovarian $\delta$-ALA-D activity inhibited by cadmium. Food Chem. Toxicol., 55: 463-469. DOI: $10.1016 /$ j.fct.2013.01.032

Tanaka, E.D. and K. Hartfelder, 2004. The initial stages of oogenesis and their relation to differential fertility in the honey bee (Apis mellifera) castes. Arthropod Struct. Dev., 33: 431-442. DOI: $10.1016 / \mathrm{j}$. asd.2004.06.006

Tanaka, E.D., W.C. Santana and K. Hartfelder, 2009. Ovariole structure and oogenesis in queens and workers of the stingless bee Melipona quadrifasciata (Hymenoptera: Apidae, Meliponini) kept under different social conditions. Apidologie, 40: 163-177. DOI: 10.1051/apido/2008071

Telfer, W.H., E. Huebner and D.S. Smith, 1982. The Cell Biology of Vitellogenic Follicles in Hyalophora and Rhodnius. In: Insect Ultrastructure, King R.C. and H. Akai, (Eds.), Springer, Boston, MA, ISBN-10: 9781461572688, pp: 118-149.

Uchida, K., M. Nishizuka, D. Ohmori, T. Ueno and Y. Eshita et al., 2004. Follicular epithelial cell apoptosis of atretic follicles within developing ovaries of the mosquito Culex pipiens pallens. J. Insect Physiol., 50: 903-912. DOI: $10.1016 /$ j.jinsphys.2004.07.002

Wallace, D.R., 2015. Environmental Pesticides and Heavy Metals - Role in Breast Cancer. In: Toxicity and Hazard of Agrochemicals, Larramendy, M.L. and S. Soloneski, (Eds.), Intech, Rijeka, ISBN-10: 9789535121459, pp: 39-70.
Wan, N., Xu, Z., Liu, T., Min and Y. S. Li, 2017. Ameliorative effects of selenium on cadmiuminduced injury in the chicken ovary: Mechanisms of oxidative stress and endoplasmic reticulum stress in cadmium-induced apoptosis. Biol. Trace Elem. Res., DOI: $10.1007 / \mathrm{s} 12011-017-1193-\mathrm{x}$

Weng, S., W. Wang, Y. Li, H. Li and X. Yu et al., 2014. Continuous cadmium exposure from weaning to maturity induces downregulation of ovarian follicle development-related SCF/c-kit gene expression and the corresponding changes of DNA methylation/microRNA pattern. Toxicol. Lett. 225: 367-377. DOI: 10.1016/j.toxlet.2014.01.012

WHO, 2011. Cadmium in drinking-water. Background document for development of WHO guidelines for drinking-water quality, World Health Organization.

Woodcock, B.A., N.J.B. Isaac, J.M. Bullock, D.B. Roy and D.G. Garthwaite et al., 2016. Impacts of neonicotinoid use on long-term population changes in wild bees in England. Nat. Commun., 7: 1-8. DOI: $10.1038 /$ ncomms 12459

Yang, S., Z.J.H. Zhang, J. Li, J. Zhang and H. Xing et al., 2012. Ovarian toxicity induced by dietary cadmium in hen. Biol. Trace Elem. Res., 148:53-60. DOI: $10.1007 / \mathrm{s} 12011-012-9343-7$.

Zelazowska, M., 2005. Structure of the ovary and the differentiation of follicular epithelium in the pig louse, Haematopinus suis (Insecta: Phthiraptera). Folia Biol. (Kraków), 53: 51-60.

Zhao, L.L., Y.F. Ru, M. Liu, J.N. Tang and J.F. Zheng et al., 2017. Reproductive effects of cadmium on sperm function and early embryonic development in vitro. PLoS ONE, 12: 1-12.

DOI: $10.1371 /$ journal.pone.0186727 